\title{
Investigation and analysis of the present situation of college students' entrepreneurial quality
}

\author{
Li Yue \\ Baicheng Normal College \\ School of Education Science 137000
}

\begin{abstract}
Through the questionnaire survey, this study has analyzed the present situation of college students' entrepreneurial quality in current Jilin province, aiming to understand the development of entrepreneurship education in current Jilin province, clear level and existing problems of college students' entrepreneurial quality in current Jilin province, provide reference to better improve and perfect the entrepreneurship education in Jilin province. Through data analysis, it found that in current Jilin province the overall level of college students' entrepreneurial quality is general, especially the entrepreneurial awareness is undefined, business knowledge is lacking, there are significant demographic differences of qualification in each dimension.
\end{abstract}

Key words: College students; Entrepreneurial quality; Status quo

\section{INTRODUCTION}

The entrepreneurship education with cultivate entrepreneurial qualities as content in our country have carried out twenty years, Jilin province is one of the earlier for entrepreneurship education province. According to the existing research point of writer, the college students' entrepreneurial quality is complex and more elemental structure, which mainly makes up of the pioneering consciousness, knowledge, pioneering ability quality, psychological quality four dimensions. Various factors influence each other and work together. Entrepreneurial awareness is the power, without it, business is impossible; Business knowledge is the foundation of entrepreneurship, is also the basic guarantee for the successful entrepreneurship; Entrepreneurship ability factor is the core, which is the most important condition of entrepreneurship success; Entrepreneurial psychological quality is the condition and guarantee, and the good psychological quality can speed up the pace of business success. On this basis, this study has carried on the questionnaire survey and statistical analysis on the current college students' entrepreneurial quality in Jilin province.

\section{Research objects and tools}

\section{(1) Object of study}

This research adopts the random sampling method to select 600 persons of parts of colleges and universities students in Jilin province as respondents of questionnaire investigation, recycling effective questionnaire 572, and effective rate was 95.3\%.Demographic characteristics distribution is 90 people of freshmen, accounting for $15.73 \%$, a sophomore of 142 people, accounting for $24.83 \%$, junior year for 190 people, accounting for $33.22 \%$, senior year for 150 people, accounting for 26.22\%; Boys of 266 people, accounted for $46.50 \%$, girls of 306 people, $53.50 \%$;Children alone of 357 people, accounting for $62.41 \%$, the children not alone of 215 people, 37.59\%.The investigation uses SPSS16.0 to process statistical data.

\section{(2) Research tools}

This research adopts the questionnaire is the existing compiled "college students' entrepreneurial quality questionnaire" in the study of author. Through the statistical analysis, the questionnaire has good reliability and validity, which measured that $1 / 2$ reliability is 
0.82 , and retest reliability is 0.76 , so it can be used as the basis of college students' entrepreneurial quality survey. The questionnaire adopts the Likert five-point scale, and subjects can choose according to each subject degree of coincidence to oneself, in order from 1 inconformity completely, 2 less inconformity, 3 between conformity and inconformity, 4 more conformity, 5 conformity completely five options. Questionnaire consists of 35 projects, including the four dimensions and 35 factors of entrepreneurial quality.

\section{Research results}
(1) Overall situation of college students' entrepreneurial quality

\begin{tabular}{|c|c|c|c|c|c|}
\hline & $\begin{array}{c}\text { Enterprise } \\
\text { consciousness }\end{array}$ & $\begin{array}{l}\text { Enterprise } \\
\text { knowledge }\end{array}$ & $\begin{array}{c}\text { Enterprise } \\
\text { ability and } \\
\text { quality }\end{array}$ & $\begin{array}{c}\text { Enterprise } \\
\text { Psychological } \\
\text { traits }\end{array}$ & $\begin{array}{c}\text { Enterprise } \\
\text { quality }\end{array}$ \\
\hline M & 3.09 & 2.98 & 3. 69 & 3.87 & 3.41 \\
\hline SD & \pm 1.305 & \pm 1.47 & \pm 1.09 & \pm 1.24 & \pm 1.45 \\
\hline
\end{tabular}

Table 1 shows four factors scores of college students' entrepreneurial quality for entrepreneurial psychological quality > pioneering ability quality $>$ business consciousness > enterprise knowledge, and entrepreneurial knowledge score is lower than average. Total score of entrepreneurial quality just exceeds average score, explaining that the overall level of current college students' entrepreneurial quality is general.

(2) Demographic differences of entrepreneurial quality of college students

With gender, grade, profession, whether is the one-child as independent variables, with every dimension of entrepreneurial qualities as a dependent variable for multiple factors variance analysis (MANOVA), the result shows that the interaction was not significant. Therefore, you can use independent sample t-test and single factor variance analysis method to analyze, investigating the demographic differences of college students' entrepreneurial quality. Among them, the different professional college students' entrepreneurial quality factors and total scores do not exist significant differences.

\section{Sex differences in college students' entrepreneurial quality}

\begin{tabular}{|c|c|c|c|c|c|c|}
\hline & & $\begin{array}{c}\text { Enterprise } \\
\text { consciousness }\end{array}$ & $\begin{array}{l}\text { Enterprise } \\
\text { knowledge }\end{array}$ & $\begin{array}{c}\text { Enterprise } \\
\text { ability and } \\
\text { quality }\end{array}$ & $\begin{array}{c}\text { Enterprise } \\
\text { Psychological } \\
\text { traits }\end{array}$ & $\begin{array}{c}\text { Enterprise } \\
\text { quality }\end{array}$ \\
\hline \multirow[t]{2}{*}{ male } & M & 3.53 & 3.17 & 3.58 & 3.94 & 3.54 \\
\hline & S D & \pm 1.249 & \pm 1.341 & \pm 1.027 & \pm 1.065 & \pm 1.146 \\
\hline \multirow[t]{3}{*}{ female } & M & 2.68 & 2.71 & 3.81 & 3.81 & 3.28 \\
\hline & S D & \pm 1.058 & \pm 1.269 & \pm 1.030 & \pm 1.224 & \pm 1.069 \\
\hline & $\mathrm{T}$ & 2. $573 * *$ & 2. $439 *$ & -.506 & -1.144 & 2. 098* \\
\hline
\end{tabular}

Table 2 shows that male and female college students in the pioneering consciousness $(\mathrm{P}<$ 0.01), knowledge $(\mathrm{P}<0.05)$ were very significantly different on the factor. The pioneering consciousness and knowledge scores of boys are significantly higher than girls; In two dimensions of the pioneering ability quality and psychological quality girls scored higher than boys, but the difference was not significant. Entrepreneurial quality score $(\mathrm{P}<0.05)$ of the boy is significantly higher than the girls. 


\section{Grade differences in college students' entrepreneurial quality}

Table 3: Single factor variance analysis of different grade students' entrepreneurial qualities of (ANOVA)

\begin{tabular}{cccccc}
\hline & $\begin{array}{c}\text { Enterprise } \\
\text { consciousness }\end{array}$ & $\begin{array}{c}\text { Enterprise } \\
\text { knowledge }\end{array}$ & $\begin{array}{c}\text { Enterprise } \\
\text { ability and } \\
\text { quality }\end{array}$ & $\begin{array}{c}\text { Enterprise } \\
\text { Psychological } \\
\text { traits }\end{array}$ & $\begin{array}{c}\text { Enterprise } \\
\text { quality }\end{array}$ \\
\hline $\mathrm{F}$ & 1.273 & 3.059 & 1.760 & 1.261 & 2.792 \\
$\mathrm{Sig}$ & .269 & $.035 *$ & .347 & .320 & $.048 *$ \\
\hline
\end{tabular}

Table 3 shows significant difference $(\mathrm{P}<$ $0.05)$ of different grade students on entrepreneurial knowledge factor and entrepreneurial quality score. Further multiple comparison results of these two factors, therefore, are shown in table 4 , table 5 .

\begin{tabular}{|c|c|c|c|c|}
\hline Dependent Variable & (I) Grade & (J) Grade & Mean Difference (I-J) & Sig. \\
\hline \multirow{12}{*}{ Enterprise knowledge } & \multirow{3}{*}{ Freshman } & Sophomore & -.019 & .831 \\
\hline & & Junior & $-.236^{*}$ & .045 \\
\hline & & Senior & $-.283^{*}$ & .036 \\
\hline & \multirow{3}{*}{ Sophomore } & Freshman & .019 & .831 \\
\hline & & Junior & -.113 & .454 \\
\hline & & Senior & -.234 & .059 \\
\hline & \multirow{3}{*}{ Junior } & Freshman & $.236^{*}$ & .045 \\
\hline & & Sophomore & .113 & .454 \\
\hline & & Senior & -.160 & .258 \\
\hline & \multirow{3}{*}{ Senior } & Freshman & $.283^{*}$ & .031 \\
\hline & & Sophomore & .234 & .059 \\
\hline & & Junior & .160 & .258 \\
\hline
\end{tabular}

Table 4 shows that college students' entrepreneurial knowledge increases along with the age growth, among them, the entrepreneurial knowledge level of freshman is relative to the minimum, and the difference of junior and senior is very significantly $(\mathrm{P}<0.05)$, while there are no significant differences between other grades.

\section{One-child differences entrepreneurial quality of college students}

Table 5: Mean and standard deviation of college students' entrepreneurial quality each factor of the one-child or not (M \pm SD)

\begin{tabular}{|c|c|c|c|c|c|c|}
\hline & & $\begin{array}{c}\text { Enterprise } \\
\text { consciousness }\end{array}$ & $\begin{array}{l}\text { Enterprise } \\
\text { knowledge }\end{array}$ & $\begin{array}{c}\text { Enterprise } \\
\text { ability and } \\
\text { quality }\end{array}$ & $\begin{array}{c}\text { Enterprise } \\
\text { Psychological } \\
\text { traits }\end{array}$ & $\begin{array}{c}\text { Enterprise } \\
\text { quality }\end{array}$ \\
\hline \multirow{2}{*}{$\begin{array}{c}\text { Not } \\
\text { only-child }\end{array}$} & M & 2.79 & 2.87 & 3.82 & 3.74 & 3.12 \\
\hline & SD & \pm 1.213 & \pm 1.246 & \pm 1.212 & \pm 1.219 & \pm 1.214 \\
\hline \multirow{2}{*}{ Only-child } & M & 3.41 & 3.11 & 3.57 & 4. 03 & 3.69 \\
\hline & SD & \pm 1.154 & \pm 1.238 & \pm 1.113 & \pm 1.135 & \pm 1.607 \\
\hline $\mathrm{T}$ & & $-2.326 *$ & -1.034 & 1. 469 & -1.006 & $-2.144 *$ \\
\hline
\end{tabular}

Table 5 shows that in addition to lower the entrepreneurial ability quality than the not-only child, other factor scores of singleton college students were higher than the not-only child, especially their Enterprise consciousness score are significantly higher than the not-only child 
$(\mathrm{P}<0.05)$;Entrepreneurial quality scores are significantly higher than the not-only child $(\mathrm{P}<0.05)$.

\section{Analysis and discussion}

(1) Analysis of college students' entrepreneurial quality overall situation

From the statistical results, total average score of college students' entrepreneurial quality is 3.41, slightly higher than scale average score, illustrating the overall level of current college students' entrepreneurial quality is general. Among them, the pioneering consciousness and knowledge score are lower, and just achieve scale score, 3.09 and 2.98 respectively. Pioneering consciousness refers to personality factors playing a dynamic role in entrepreneurial activity, which has an important driving force for entrepreneurs to engage in entrepreneurial activities. Where there are the pioneering consciousnesses, there are entrepreneurial activities. The pioneering consciousness mainly consists of the business needs, entrepreneurial motivation, interest, ideal, four aspects; Entrepreneurial knowledge refers to the entrepreneurial activity related knowledge system and its structure, including two aspects of professional knowledge and management knowledge. Sufficient knowledge can provide knowledge guarantee for business success. Seen from the above results, at present there are few college students who have a clear business desires and motives, and their knowledge of entrepreneurship is not rich enough. Entrepreneurship education in our country although has also been carried out twenty years, but the main targets of entrepreneurship education are minority college students, and the entrepreneurship education implementation and entrepreneurial quality improvement still not fully spread to every college student, therefore students who have stronger entrepreneurial awareness and richer entrepreneurship knowledge are minority.

In the statistical results, average score of entrepreneurial ability quality and entrepreneurial psychological quality were 3.69 and 3.69 respectively, relatively high. The pioneering ability quality is comprehensive psychological conditions to ensure the successful entrepreneurship, and is a comprehensive ability, the high or low level directly determines the stand or fall of enterprise performance of entrepreneurs; Entrepreneurial psychological quality refers to the content of the subject's personality characteristics, and in the entrepreneurial activity it has the very good regulating effect on psychological and behavior of main body, which mainly consists of emotion and will feature. Entrepreneurial ability quality and entrepreneurial psychological quality are closely associated with their own ability and personality characteristics of individual, and the formation of these qualities are influenced both the genetic factors and acquired environment and the role of education, therefore, college students who have contacted with entrepreneurship education are able to form a certain entrepreneurial ability quality and entrepreneurial psychological quality. But restricted by various factors, these qualities are difficult to reach a higher level, especially the insight, emergency ability, dare, decisiveness, compressive resistance, sharpness and other personal qualities.

(2) Demographic situation analysis of college students' entrepreneurial quality

Results suggest that male college students have higher pioneering consciousness and knowledge than girls significantly $(\mathrm{P}<0.05)$, illustrating boy usually have stronger entrepreneurial motivation and ideas. In our traditional idea, the man want to have own business, who is the pillar of family life. In today with serious employment situation, own business is nothing but a better way, so that more boys have entrepreneurial ideas and desires. It also makes them pay more attention to entrepreneurial knowledge and information in life and learning of, thereby increasing their business knowledge and accomplishment. Their entrepreneurial qualities have more significant 
differences than girls $(\mathrm{P}<0.05)$.

Through the single factor variance analysis, it found there are significant differences on different grade students in entrepreneurial knowledge factor. After multiple comparisons, it found that its significant differences mainly embody between freshman and junior, senior year $(\mathrm{P}<0.05)$. Freshmen who just enter college, still are immersed in the new university life, without a good plan for future, nor can ask myself to learn business knowledge; Junior and senior students who will really step into society, after several years of university life, has been more prepared for their future, especially students who have stronger entrepreneurial awareness, who in the students life pay more attention to the knowledge of the business class, and after a few years of university entrepreneurship education, also accumulated more entrepreneurial knowledge, so the score is higher.

Only-child college students' pioneering consciousness level and quality scores are significantly higher than the singleton female $(\mathrm{P}<0.05)$. There are not significant difference in other aspects. With China's economic society development and the implementation of the one-child policy, there are more and more one-child families, and their family economic conditions are better than families with many children, which provides good economic security for only children entrepreneurship. In addition, from the point of view of personality traits, children alone tend to have more adventurous and challenging spirit, who hope to realize own value through entrepreneurship, proving their ability. And college students from families with many children who can rely on family economic support are relatively less, which is a big obstacle to implement entrepreneurship, and they hope to learn and accumulate better professional knowledge and experience through four years of university, ready to find professing, relatively stable job, no longer add burden to family and give some financial help for the home as soon as possible, so that their awareness are not strong.

\section{CONCLUSIONS}

To sum up, in the current Jilin province the overall level of college students' entrepreneurial quality is general, especially need to emphasize particularly on the cultivation of college students' entrepreneurship awareness and business knowledge learning, increase business practices, and give students a better opportunity to exercise.

Project: *education science key self-help topics in Jilin province(ZC13111)

\section{References}

[1] Peng Gang. Entrepreneurship education [M]. Nanjing: Jiangsu Education Press, 1995.85

[2] Chen Yan, Lei YuSheng, Cao Ranran. Investigation and thinking of college students' entrepreneurial quality [J]. Journal of Higher Education to Explore, 2006 (4)

[3] Zhao Shuling. The present situation problems and countermeasures research of our college students' entrepreneurship education $[\mathrm{J}]$. Journal of Jiangxi University of Science and Technology, 2010 (2)

[4] Lin Li. Cultivation analysis of college students' entrepreneurial quality [J]. Journal of Ideological and Theoretical Education Tribune, 2010 (8)

[5] Zeng Yuan. Present situation, problems and education countermeasures study of college students' entrepreneurial quality [J]. Journal of Jiangxi University of Science and Technology, 2011, 32 (4) 